\title{
BAPTISM IN IRENAEUS OF LYONS: TESTIMONY TO AND PARTICIPATION WITH THE TRIUNE GOD
}

\author{
Christopher A. GrAHAM * \\ Criswell College
}

\begin{abstract}
Irenaeus of Lyons wrote Demonstration of the Apostolic Preaching (Epideixis) to encourage his readers of the solidity of their faith, especially as this faith was connected to baptism under the threefold seal: Father, Son, and Holy Spirit. The threefold nature of the baptismal formula drives Irenaeus' discussion in Epid. 3-7 and is the point with which he concludes the work, saying, 'error, concerning the three heads of our seal, has caused much straying from the truth' (Epid. 100). Irenaeus structures the intervening chapters to show how Christian baptism is both a testimony to and participation with the Triune God referenced in the baptismal formula. The lack of explicit structural markers within the body of the text has resulted in a neglect of the trinitarian character of its structure. This article explores the manner in which Irenaeus of Lyons' Demonstration provides insight into his understanding of the nature and activity of the Triune God based on his conviction that Christian baptism is both a testimony to and a participation with that Triune God.
\end{abstract}

KEYWORDS: Irenaeus, Demonstration, baptism, genealogy, Valentinian

\section{Introduction}

Irenaeus declares his intention for writing Demonstration early in the preface:

We have not hesitated to speak a little with you, as far as possible, by writing, and

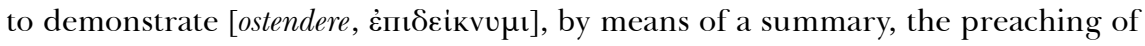
the truth, so as to strengthen your faith. We are sending you, as it were, a summary memorandum, so that you may find much in a little, and by means of this small (work) understand all the members of the body of the truth, and through a summary receive the exposition of the things of God, so that, in this [manner], it will bear your own salvation like fruit, and that you may confound all those who 
hold false opinions and to everyone who desires to know, you may deliver our sound and irreproachable word in all boldness (Epid. 1). ${ }^{1}$

Irenaeus accomplishes his central purpose of strengthening the reader's faith in the body of the work by reinforcing the subjective side of the reader's faith and not primarily by holding out content (i.e., doctrine, narrative history, the accuracy of the apostles' preaching) so as to strengthen the object of the reader's faith, as is often assumed. Immediately after his exhortation to 'keep the rule of faith' Irenaeus says, 'The truth brings about faith, for faith is established upon things real, that we may believe what really is, as it is, and (believing) what really is, as it is, we may always keep our conviction of it firm' (Epid. 3. See also Haer. 2.10.2). This faith is tied to a proper estimation of baptism especially inasmuch as this baptism takes place under three articles: God the Father; Jesus Christ, the Word or Son of God; the Holy Spirit of God. The threefold nature of the baptismal formula then drives his discussion in five introductory chapters (Epid. 3-7). Because baptism and faith are not exempt from the fact that 'all things that have come into being have received the origin of their being from some great cause', the reader's baptism and faith themselves have a genealogy signified in the threefold sign of baptism (Epid. 4). Being cognizant of the genealogy of his or her baptism, the subjective side of faith, the reader is fortified to hold fast to the 'rule of faith' (see also Haer. 5.11.2).

Irenaeus draws attention to the trinitarian baptismal formula as signifying the work of the true God to demonstrate the legitimacy of the reader's faith:

And this is the order of our faith, the foundation of (the) edifice and support of (our) conduct: God, the Father, uncreated, uncontainable, invisible, one God, the Creator of all: this is the first article of our faith. And the second article: the Word of God, the Son of God, Christ Jesus our Lord, who was revealed by the prophets, according to the character of their prophecy and according to the nature of the economies of the Father, by whom all things were made, and who in the last times to recapitulate all things, became a man amongst men, visible and palpable, in order to abolish death, to demonstrate life, and to effect communion between God and man. And the third article: the Holy Spirit, through whom the prophets prophesied and the patriarchs learnt the things of God, and the righteous were led in the [way] of righteousness, and who, in the last times, was poured out in a new fashion upon the human race renewing man, throughout the world, to God. For this reason, the baptism of our regeneration takes place

1 The text of Demonstration used throughout this article relies primarily on the English translation of Behr (2000), with consultation of the Latin translation of Rousseau (1995). 
through these three articles granting us regeneration unto God the Father through His Son by the Holy Spirit (Epid. 6-7).

Within the subsequent exposition that comprises the body of the work, we gain insight into Irenaeus' understanding of the nature and activity of the Triune God. I will draw attention to three significant areas that arise from this exposition based on Irenaeus' conviction that Christian baptism is both a testimony to and a participation with that Triune God.

\section{Baptism Is a Testimony to and Participation with the Triune God because of its Trinitarian Genesis}

Irenaean scholars continue to provide a nuanced understanding of what is an obvious and central plank in Irenaeus' polemic against his opponents, namely, that protological creation and salvific re-creation are properly and necessarily trinitarian acts (see, for example, Fantino 1994; Behr 2000a; Steenberg 2008; Lashier 2014). As a bishop concerned with the eternal welfare of his flock, Irenaeus is compelled to defend the fundamental truth that the God who is active in the regeneration of individuals was the Creator active in the creation narrative of Genesis. The trinitarian acts of God, however, ought not to be limited to protological creation and salvific recreation broadly construed. As M. C. Steenberg observes in his study, Irenaeus on Creation: The Cosmic Christ and the Saga of Redemption: 'Baptism, redemption, divinization, resurrection, eternal life-all are triune events wrought in a cosmos formed and fashioned by that this [sic] triad' (Steenberg 2008: 62). Before turning to the manner in which Irenaeus' concern for baptism's trinitarian genesis is manifest in his Demonstration, it is helpful to consider an instance where Irenaeus treats baptism in Against Heresies.

Within the exposé of his opponents' systems in book one, Irenaeus characterizes the redemption offered by his Marcosian opponents as unstable

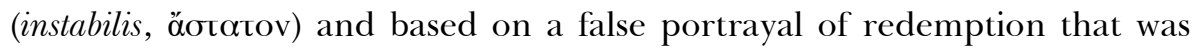
intended to 'deny the baptism of regeneration unto God, and destroy the entire faith' (Haer. 1.21.1). He then describes the variety of baptismal practices among his opponents. Some eschew the legitimacy or sufficiency of water baptism. Others practice water baptism but employ a wide variety of formulas when doing so. Some, for example, use the formula into the name of the unknown Father of the universe, into Truth (the Mother of all), into the one who descended upon Jesus...' (Haer. 1.21.3). Others 'pronounce some Hebrew names over those who are being initiated in order to bewilder them even more', which are interpreted as 'above the Father's every power, which is called Light and good Spirit and Life...' (Haer. 1.21.3). Others invoke 'the name which has been hidden from every Deity, Dominion, and Truth, with which Jesus the Nazarene clothed himself in the region 
of the light of Christ—who lives by the Holy Spirit for the angelic service' (Haer. 1.21.3).

Irenaeus moves directly and with no explanatory comment from this exposé of his opponents' baptismal practices to an articulation of the 'Rule of the Truth that we hold' (teneamus autem nos regulam ueritatis) (Haer. 1.22.1). After articulating the Rule of Truth, Irenaeus says that 'If, therefore, we hold fast this Rule (tenentes regulam), we shall prove that they have strayed from the truth, even though their statements are quite varied and numerous (ualde uaria et multa).' Juxtaposing a disparaging comment about his opponents' diversity with a commendatory comment about the Church's unity is a frequent rhetorical device in Irenaeus' writings and manifests his convictions about the essential and virtuous nature of ecclesial unity (see also Haer. 2.9, 3.12.5-7, 5.20, Epid. pref. 1; cf. Kereszty 1984). Having just considered the disparate variety found in the baptismal practices of his opponents, though, why would Irenaeus not make use of the trinitarian baptismal formula to demonstrate the Church's unity? It is likely due to the connection that Irenaeus saw between baptism and the Rule of Truth.

Earlier in the book, Irenaeus had spoken of 'the Rule of Truth received

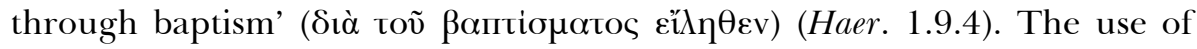
the Rule of Truth as an indicator of the Church's unity, including its use in Haer. 1.22 as a response to the erroneous baptismal practices of his opponents, should be read within the purpose that Irenaeus articulates in his opening sentence of Against Heresies: 'Certain people are discarding the

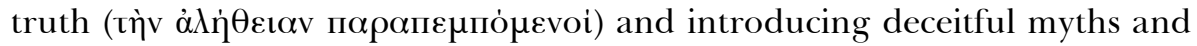

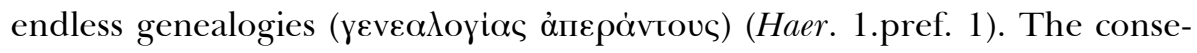
quence of the teaching of endless genealogies is that it brings "many to ruin by leading them, under the pretense of knowledge, away from Him who established and adorned this universe, as if they had something more sublime and excellent to manifest than the God who made heaven and... all things in them' (Haer. 1.pref. 1). Irenaeus' predominant strategy in Against Heresies 1 is to expose these endless genealogies, but occasionally he articulates what he holds to be the true geneaology as it is manifest in the Rule. Although he never explicitly refers to the Rule of Truth as a genealogy, its substance certainly includes elements of one. Here, for example, it emphasizes the identity of God as the Creator: 'There is one God Almighty, who created all things through His word; He both prepared and made all things out of nothing... Now, it is the Father who made all things though Him... He made all things by His Word and Spirit, disposing and governing them and giving them all existence' (Haer. 1.22).

That Irenaeus has in mind the baptismal formula as he articulates the Rule of Truth here in Haer. 1.22 is given further support if, in fact, Jackson Lashier is correct that 'one agent theology of creation... generally domi- 
nates the theology of Haer. 1-3' and that the mention of the Spirit here is an anomaly (Lashier 2014: 169; cf. Brigmann 2012: 97-103). Lashier suggests that Irenaeus includes the Spirit merely 'as part of the teaching passed down from the apostles' (Lashier 2014: 165). Perhaps, however, it is because the Rule was handed down in and through baptism, which includes the clear reference to the Spirit's role in baptism.

In Against Heresies 1, the Rule itself sufficiently demonstrates the unity of the Church, both in the content of what it teaches and as the result of the work of the one true Creator God. The polemical purpose of Against Heresies compelled Irenaeus to begin with an exposé of his opponents' variety of imagined genealogies and to mention only occasionally the one genealogy of the Church; however, his purpose in Demonstration compels him simply to begin at the proper genesis of baptism: the trinitarian God's actions at the creation of the world. To fortify the one who has received faith through a trinitarian baptism, Irenaeus lays out in a more exhaustive manner the divine genesis of baptism. As Irenaeus demonstrates in his opening chapters, creation is the result of the Father working by the Son and Spirit-the same Father, Son, and Spirit named at baptism.

Irenaeus does not begin his exposition at creation (Epid. 8) merely because it is the beginning of the scriptural narrative found in the Jewish and Christian scriptures. He begins with creation because he must establish that the Father named in the baptismal formula is, in fact, active as the Creator of Genesis. By his own account in Against Heresies, even Irenaeus' opponents invoke the name of a father in their baptismal formulas. But as his exposé also demonstrates, their father is not identified as the creator of Genesis. Though not as overtly or directly polemical as Against Heresies, neither is Demonstration 'non-polemical' or 'non-apologetic' (Behr 2000b: 7). Certainly those against whom Irenaeus contends in Against Heresies are still active during the composition of Demonstration. Irenaeus' exhortation in Demonstration's preface for the reader to stay on the one way that leads upward rather than taking one of the diverse ways that leads downward echoes the language that he uses in Against Heresies when juxtaposing the Church's position against that of his opponents (see, for example, Haer. 5.19-20). Irenaeus must assure Marcianus, the intended recipient of Demonstration, that his baptism and associated redemption in the name of the trinitarian God summoned the same God active in protological creation.

When Irenaeus turns to the second article of the formula-the Son-in Epid. 43, he again draws the reader's mind back to creation as the genesis of baptism to assure the reader that the Son of the baptismal formula was also active in creation. Lashier notes that Irenaeus' general tendency is to employ the word Logos when referring to the pre-incarnate state of the second person of the Trinity. Irenaeus even adds 'Logos imagery to certain inter- 
pretations of scripture passages that involve only Father-Son language in order to emphasize the continuity of the revealing work of the preincarnational Logos and those actions performed by (or rather manifested in) the incarnate Son of God' (Lashier 2014: 124). In Epid. 43, however, Irenaeus does just the opposite. Here he employs the Johannine Prologue but adds 'filial language to passages that only possess Logos imagery' (Lashier 2014: 125, n. 136). This would make sense if Irenaeus wants to utilize John's convenient reference to the activity of the second person of the Trinity at creation, but is being guided by the language of the baptismal formula wherein the second person is referred to not as Logos but as Son.

For as important as the protological, creative actions of the trinitarian God are in establishing the trinitarian nature of baptism, Irenaeus does not merely set them in direct correlation with God's re-creative actions as he does when he draws recapitulative correlations between Genesis and the work of Christ and the Church. It is equally important for Irenaeus to demonstrate that baptism is a result of the continuous action of the trinitarian God in history from creation until the time that baptism is being conducted. That is, for Irenaeus, protological creation was truly the genesis of baptism because that which the trinitarian God created, He subsequently guided to the time of the reader's baptism. That is to say, baptism is a testimony to and participation in the Triune God because of its trinitarian genesis and subsequent genealogy.

\section{Baptism Is a Testimony to and Participation with the Triune God because of its Trinitarian Genealogy.}

Irenaeus goes to great lengths to demonstrate the continuity of God's actions from creation until the present. This continuous work of God in history is evident in the Rule of Truth that is received by means of baptism, and it is evident in the body of Demonstration, especially as Irenaeus moves chronologically forward from the point of creation. At times in recent scholarship, the narratival character of the Rule and Demonstration has taken center stage. Nathan MacDonald rightly observes, however, that 'Irenaeus's intent is misconstrued when his work is read as an elaboration of the Rule of Faith understood as a scriptural narrative running from creation to consummation' (MacDonald 2009: 293). He goes on to say that 'the Rule of Faith is not identical with Scripture, nor does it trace Scripture's narrative plot. Rather, the Rule of Faith provides Scripture's hypothesis. This hypothesis concerns the unified actions of Father, Son, and Holy Spirit, most especially the salvific events of the Son...' (MacDonald 2009: 290). MacDonald's observations about the trinitarian intent of Demonstration are helpful; nonetheless, even MacDonald's structural explanation does not properly account 
for the work's purpose, which is to fortify the reader's faith in the trinitarian God active in baptism.

Assuming a bipartite structure of Demonstration, MacDonald is compelled to explain the relationship between the two parts (Epid. 6-42a; Epid. 42b97). He rejects the notion that the second part is merely a retelling of the first (see, for example, Graham 2001). Instead, MacDonald reckons that 'the OT Scriptures are dealt with by Irenaeus according to a twofold form' (MacDonald 2009: 293). For MacDonald then, 'the difference lies in the books of the OT from which he [Irenaeus] draws his argument. Epid. 8-42a draws on the historical books from Genesis-2 Kings, whereas Epid. 42b-97 appeals to the major and minor prophets' (2009: 293).

MacDonald also acknowledges the difficulty in accounting for the latter chapters of the first part (Epid. 31-42a), since "it should be immediately apparent that Irenaeus covers the very same truths about Christ in chs. 31-42a that he will cover in the second half of Demonstration' (MacDonald 2009: 293). Again, MacDonald's resolution to this difficulty is bibliological. While Irenaeus draws from the historical books of the OT in the whole of the first part (Epid. 8-42a), there is a difference between his use of these books in Epid. 8-30 and his use in Epid. 31-42a. In Epid. 8-30, 'Irenaeus does trace the narrative flow of Genesis-2 Kings' because 'this belongs to the givenness of one part of the OT canon' (MacDonald 2009: 294). In Epid. 31-42a, however, Irenaeus shifts to a 'theological reading of Genesis-2 Kings [which] is better described as figural, rather than narratival' (MacDonald 2009: 294). MacDonald assumes that this shift happens because Irenaeus moves in Epid. 31-42a to 'a coordinating of the history of Genesis-2 Kings with the salvific actions of Jesus Christ' (MacDonald 2009: 293). That is, MacDonald, assumes that the object of discussion has shifted from the Father to the Son at Epid. 30.

This, however, is a misreading of the shift that occurs in Epid. 30-34 because of a failure to recognize that Irenaeus is tracing the trinitarian genesis and genealogy of faith and baptism according to the summary provided in Epid. 6. In the language of Epid. 6, the shift is from 'God, the Father, uncreated, uncontainable, invisible, one God, the Creator of all' to 'the nature of the economies of the Father, by whom all things were made' including specifically the prophecies and actual enactment of the salvation through Christ and the Spirit. The shift, then, is not from Father to Son. The shift is from the Father's oversight of creation to the Father's oversight of the economic activity leading to salvation. That is, in Epid. 30-42a Irenaeus demonstrates that the Father's economic oversight, through his Word and Spirit, was preparing humanity for the redemption that would be offered in the advent of his Son and the pouring out of his Holy Spirit. With regard to the former, for example, Irenaeus asserts twice in Epid. 32 that it was according to 
the 'will and wisdom of God (ex voluntate et sapientia Dei)' that God both created Adam from virgin earth and brought forth Christ from a virgin. Irenaeus summarizes this section in Epid. 35-37 by emphasizing God as the promise maker and the Son as the fulfillment of those promises: 'rich in mercy was God the Father: He sent the creative Word' (Epid. 37).

This section ends in Epid. 40-42 as Irenaeus turns his attention to the culmination of the Father's economic oversight in the giving of the Spirit: 'For thus do the faithful keep, having the Holy Spirit constantly dwelling in them, who was given from Him at baptism (qui datur in baptismo) and kept by the recipient living in truth and holiness and righteousness and patience' (Epid. 42). ${ }^{2}$ Having traced the genesis and genealogy of baptism under the oversight of the Father through Epid. 42, Irenaeus now traces the Son's role in baptism's genealogy beginning in Epid. 43. As noted above, he first establishes the Son's presence in the genesis of baptism at protological creation. He then moves to demonstrate the Son's activity in history after creation. (MacDonald believes that what distinguishes the section after Epid. 42a is an appeal to the prophetical rather than historical books. Against MacDonald's claim, however, is the fact that Irenaeus continues to appeal to the historical books in the chapters after Epid.42a. This section comes to an end in Epid. 86 with another affirmation of the assurance that, on the basis of the preceding exposition, 'firm [is] our faith in Him and true is the tradition of preaching, that is the witness of the apostles (firma e [st] nostra in eum fides et vera praedicationis tradition, hoc est apostolorum testimonium)'.

Not only did the Triune God create the very elements that He will then use in regeneration associated with baptism, he was actively involved in this world from the point of creation to the point of recreation. The reason for Irenaeus' insistence on the genealogy that lay behind baptism is not merely truth for truth's sake. Only by embracing the preaching of the Church, which manifests and testifies to the reality that it is itself rooted in the Triune God active from protological creation, does one participate in the redemption of God. This leads to the final area of insight to be drawn from Demonstration regarding the trinitarian nature of baptism, namely, the manner of the participation with this Triune God in redemption.

\section{Baptism Is a Testimony to and Participation with the Triune, Revelatory God}

Irenaeus refers to the baptismal practices of his opponents toward the end of Against Heresies 1 only after he has considered their pleromatologies and cosmogonies. Only once in this section does Irenaeus explicitly link these 
baptismal practices to an underlying divine genealogy and the consequent nature of redemption. There are some "who say that it is useless to lead the people to the water' (Haer. 1.21.4). They are among those who do so be-

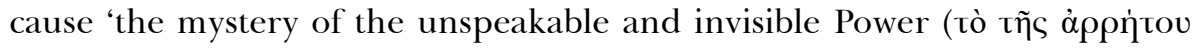

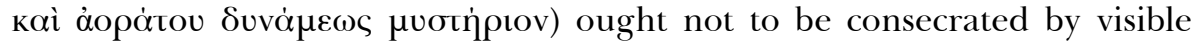
and corruptible creatures' because, as Irenaeus has pointed out in his genealogical exposé, they reject the identity of the father as the creator in Genesis. For these, then, redemption is neither corporeal nor ensouled but only spiritual and 'the very knowledge of the unspeakable Greatness (тov

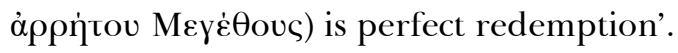

Of those who practice water baptism, Irenaeus does not explicitly connect their baptismal practices to their pleromatology or their understanding of redemption. The wording of the baptismal formulas, however, does provide a clue as to these connections. Two of the baptismal formulas draw attention to a key element in the Marcosian system: the unknowability of God. Some, Irenaeus says, baptize 'into the name of the unknown Father of the

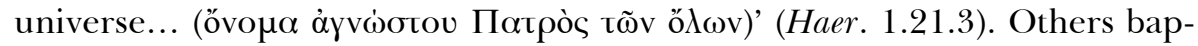

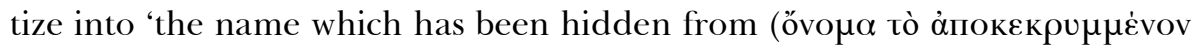
ảnó) every Deity, Dominion, and Truth...' (Haer. 1.21.3). In his pleromatological sections, divine unknowability is linked to divine silence (бıүท่).

Irenaeus indicates that, in some pleromatologies, silence is an attribute of the Father. In Haer. 14.1, for example, he speaks of a system in which the Father, wishing for that which was unspeakable to be spoken, opened his mouth. Only at this point was the Word generated. And in his opponents' interpretation of Matthew 21:24-27, Jesus' silence in response to his interrogators' questions is a manifestation of the Father's unspeakable nature (Haer. 1.20.2).

In other pleromic systems that Irenaeus considers, however, silence is not merely an attribute of God. Silence is a hypostasis of the highest order. For some, Silence, along with three other hypostases (Father, Unutterable, and Truth) form the Tetrad from which all else is generated. In his repeated references to his opponents' claim that Silence is the revelatory agent of that which is unknowable (Haer. 14.2, 14.4, 14.7, 15.1), the reader senses that Irenaeus is drawing attention to the irony inherent in this system even before he points out the absurdity of these contradictions (Haer. 15.5).

Steenberg asserts that there is 'a matrix of theological expression that involves a more intimate degree of similarity between Irenaeus and his foes, and which must cause us to raise questions about what such common expression might mean' (Steenberg 2011: 90). The polemical rhetoric in Against Heresies can attenuate the reality that there are points of commonality between Irenaeus and his opponents. With that in mind, it is helpful to turn to a text arising from one of Irenaeus' antagonistic communities. 
Though Irenaeus does not discuss baptism when considering his Valentinian opponents in Against Heresies, we have the topic preserved in Tripartite Tractate, a text that reflects the centrality of baptism in a Valentinian community. As Einar Thomassen observes of the tractate, in the final analysis salvation is realized in the practice of baptismal initiation' (Thomassen 2006: 57). It begins:

As for the true baptism, that into which the Entireties descend and where they come into being, there is no other baptism save that one only-and that is the redemption-(which takes place) to God through Father, the Son, and the Holy Spirit, after a confession of faith has been made of those names-[which] are the single name of the good tidings - and after one has believed that the things one has been told are real. And on account of this, whoever believes in their reality will obtain salvation... (Tri. Trac. 127.25-128.5).

Everett Ferguson observes of this text that 'the characteristics and benefits ascribed to baptism sound very much like orthodox statements: the necessity of faith with hope and its confession $(128.1,5,9,11-12,17-18)$, the use of the triple divine name (also in 128.5), salvation (128.4), perfection (128.13), and redemption (128.24)' (Ferguson 2009: 284). To this list belongs another point of commonality between Irenaeus and his opponents: the conviction that the God named in the baptismal formula and in whom one professes faith is the same God at work in and through that baptism. For both Irenaeus and his opponents, the legitimacy of an individual's faith and baptism are tied to understanding the true nature and identity of the God. It is this conviction that compels Irenaeus to devote the entirety of Demonstration to demonstrate the genealogical truth indicated by the words 'Father, Son, and Spirit'.

Though the Tripartite Tractate does not have an introductory explanation of its purpose, what precedes the explanation of baptism is a genealogical exposition beginning with the first principles: the Father; the Son; and the Church, which exists as the result of the mutual love between the Father and the Son. From the will of the Father and through the Church emanate 'innumerable births of aeons, and these in turn give birth in infinite number through the qualities and properties in which they [exist]' (Tri. Trac. 59). ${ }^{3}$ In order that they might perceive who they have as a father, "The Name of the Father he granted them, by means of a voice calling out to them that he who is, is by that Name, and possessing it, one comes into being. How exalted the Name was, however, they did not realize' (Tri. Trac.

3 The English translations for Tripartate Tractate throughout this article are taken from that of Thomassen as found in The Nag Hammadi Scriptures (Meyer 2007), unless otherwise noted. 
61). All of the aeons, then, exist in his single Name, and the Father is 'each and every one of the members of the All eternally at the same time. He is what all of them are, as Father of the All, and the members of the All are the Father as well' (Tri. Trac. 66-67). The Father, however, is unknowable, and even He is himself unnamable (Tri. Trac. 66, 73). It is only after a lengthy exposition of these first principles that one encounters the creation of the world. For Irenaeus, as noted above, the creation of the world is itself the proper starting point of a genealogy of baptism.

Just after the passage quoted above regarding the tri-fold baptismal formula, the Tripartite Tractate goes on to specify that baptism is also 'called "silence" because of its tranquility and unshakeability' (Tri. Trac. 128.30-32). The exposition ends by saying:

Thus, it is called after all the fair things it contains, including the (names) that have been [left out], in a manner that is simple, authentic, indivisible, irreducible, complete, and unchangeable. For how else can it be named, save by referring to it as the Entireties? That is, even if it is called by innumerable names, they are spoken (only) as a way of expressing it in certain ways, although it transcends all words, transcends all voice, [transcends] all mind, transcends all things, transcends all silence. That is how it is $[\ldots]$ with the things that belong to what it is. That is what in fact it is, with the things that belong to what it is. This is what in fact it is, with an ineffable and inconceivable character in order to be in those who have knowledge by means of what they have attained, which is that to which they have given glory. Tri. Trac. 128.32 (Thomassen 2006: 180).

In Tripartate Tractate, then, silence is not a distinct aeon but is an essential attribute of the Father and of the relationship between the Father and the Son. The Father, although unknowable and ineffable, can grant knowledge; however, prior to the generation of the members of the entirety 'he holds himself back in silence' (Tri. Tract. 55.35-36). His self-reflective activity is properly termed 'Silence' (Tri. Tract. 55.35-36), and in his self-generative activity 'he has as a Son dwelling in him, keeping silent about him, and this is the ineffable within the ineffable...' (Tri. Trac. 56.23-27).

For Irenaeus' opponents, then, silence is a part of the divine nature, and unknowability marks the nature of the relationship between God and humanity. Silence lies at the intersection of the divine nature, baptism, and redemption. In his opponents' interpretation of Jesus' baptism, the dove that descends at Jesus' baptism is the Father's seed 'which has in itself both Father and Son, and the unnameable power of Silence which is known

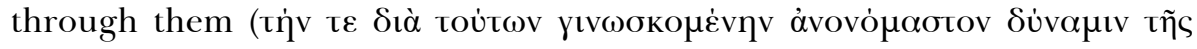
$\Sigma$ ıүच̃ $)$ and all the Aeons. And this is the Spirit who spoke by the mouth of Jesus, confessed himself to be Son, manifested Father, and when he descended upon Jesus, was made one with him' (Haer. 1.15.3). And in the Tri- 
partite Tractate, the salvific participation connected with baptism is characterized by silence.

For Irenaeus, however, revelation lies at this same intersection. Whereas silence is an attribute of God and an agent of revelation in his opponents' system, the Word and Spirit are the agents of God's revelation stemming from, Irenaeus says, his very nature. After asserting in his introduction that 'all things that have come into being have received the origin of their being from some great cause' (Epid. 4), Irenaeus goes on to say that there is 'one God, [the] Father, uncreated, invisible, Creator of all, above whom there is no other God, and after whom there is no other God. And as God is verbal (loyıkós), therefore He made created things by the Word; and God is Spirit, so that He adorned all things by the Spirit' (Epid. 5). He immediately proceeds to say, 'thus, the Spirit demonstrates the Word, and, because of this, the prophets announced the Son of God, while the Word articulates the Spirit, and therefore it is He Himself who interprets the prophets and brings man to the Father' (Epid. 5). For as important as the two-agent creative and providential work of God is throughout Demonstration, equally central is the two-agent revelatory action of God. In fact, the creative and revelatory work are so closely intertwined for Irenaeus that it is both of these together that prepared humanity for the redemption that they would receive.

According to at least some of Irenaeus' opponents, there was no

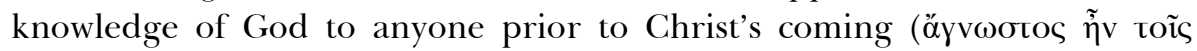
$\tau \tilde{\alpha} \sigma \mathrm{l})$ since all anyone knew of was the creator (Haer. 1.19.1). Even in the present, his opponents claim to have knowledge of the unknowable God who is above the creator and they draw the language of being baptized into

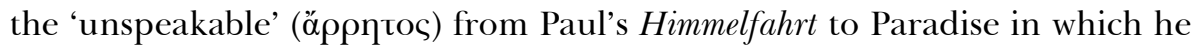

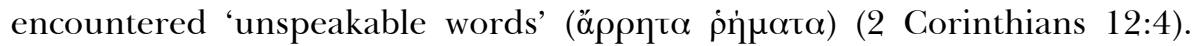
Though it seems clear that his opponents have drawn from 2 Corinthians 12:1-7 in the pleromatologies and description of redemption as Irenaeus recounts these in the first book, it is only in Haer. 5.5-6 that he responds directly to their interpretation and sets out his own understanding of this passage.

For Irenaeus, however, God's relationship with humanity from creation has been marked by revelation. In Paradise, the same Word by which God created 'would walk and talk with man (Verbum Dei adsidue in eo deambulabatcircumibat et loquebatur cum homine) prefiguring the future, which would come to pass, that He would dwell with him and speak (loquetur) with him, and would be with mankind teaching them righteousness' (Epid. 12). While his opponents disparaged the Jewish prophets and would avoid any claim of

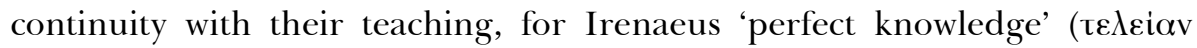
yvõovv) gained in the present does not circumvent the prophetic testimony 
but is in continuity with it (Haer. 1.21.1). In Haer. 4.25.3, Irenaeus speaks of the prophets sowing and the Church reaping the fruit of scripture, which leads into the discussion about finding Christ in scripture through which knowledge is completed and disciples are perfected (see also, Haer. 1.31.2-3; 2.9.2, 13.10, 24.1, 25.4; 3.pref., 15.2). This redemptive knowledge is a work of the trinitarian God accomplished through the prophets. The Spirit, he says, was 'conforming Himself to the person concerned, spoke in the prophets (in prophetis loquebatur), producing words (faciebat sermones) sometimes from Christ and at other times from the Father' (Epid. 49; cf. Epid. 24, $30,47)$. When Irenaeus brings to a conclusion his discussion of the work of the Father, He draws attention to the revelatory work of the Father, Son, and Spirit in the prophets, in John the Baptist, in the apostles, and in the Church. This revelation results in the fact that the faithful keep the body stainless and the soul uncorrupted, 'having the Holy Spirit constantly in them, who was given from Him at baptism and kept by the recipient living in truth and holiness and righteousness and patience' (Epid. 42).

\section{Conclusion}

For Irenaeus, baptism is not merely trinitarian because it has been stamped as such by the affixing of a trinitarian formula. Baptismal formulas are employed by Irenaeus and his opponents to signify the nature of the God active in that baptism and the resultant nature of redemption. This is why Irenaeus must expose the in-significance of his opponents' baptismal formulas and demonstrate what the trinitarian baptismal formula does signify. His opponents' baptism is in-significant. This, Irenaeus explains, is demonstrated in their interpretation of Jesus' baptism:

They make a collection of foolish discourses that they might come to this knowledge, [namely], to know that the Lord indeed came to the baptism of the truth at the age of thirty, but without learning this [the meaning of the baptism], they impiously scorn the very God who is Creator and who sent the Lord for the salvation of humankind... without believing that God made those things that were made in order that all things might exist out of things that did not exist... In this way they really manifest their unbelief, since they do not believe in the things that exist, but have fallen into what does not have existence (Haer. 2.10.2)

Irenaeus writes Demonstration to bolster the faith of his reader, Marcianus, by reinforcing the truth that his baptism and regeneration are rooted in the truth. Irenaeus tells Marcianus that his goal is that 'you may be pleasing to God, your Creator' (Epid. 1). This could only be a proper goal if, in fact, the God (Father, Son, and Spirit) named at baptism is, in fact, the Creator. It is necessary for Irenaeus to emphasize that the God who created humanity now re-creates individuals, and this regeneration is not a circumvention of 
the work that God has done through history but a result of that work. Not only is the faith and baptism available in the Church rooted in that which is true, these are the very means by which one participates with God in redemption. Though this redemptive relationship has many aspects, God's revelatory presence is one of its central facets. The trinitarian God who created and sustained humanity is the same trinitarian God with whom genuine redemptive knowledge is possible.

\section{Bibliography}

Barnes MR (2009) Irenaeus's Trinitarian Theology. Nova et Vera 7(1): 67106.

Behr J (2000a) Asceticism and Anthropology in Irenaeus and Clement. Oxford: Oxford University Press.

Behr J (ed) (2000b) On the Apostolic Preaching: Translation and Introduction. Crestwood, NY: St. Vladimir's Seminary Press.

Briggman A (2012) Irenaeus of Lyons and the Theology of the Holy Spirit. Oxford: Oxford University Press.

Fantino J (1994) La théologie d'Irénée: Lecture des Écritures en réponse à l'exégèse gnostique. Une approche trinitaire. Paris: Éditions du Cerf.

Ferguson E (2009) Baptism in the Early Church: History, Theology, Liturgy in the First Five Centuries. Grand Rapids, MI: Eerdmans.

Graham SL (2001) Structure and Purpose of Irenaeus' Epideixis. Studia Patristica 36(*): 210-221.

Irenaeus (1979) Irénée de Lyon: Contre les hérésies, Livre 1, Rousseau A and Doutreleau L (eds and trans) (Sources chrétiennes 263). Paris: Éditions du Cerf.

Lashier J (2014) Irenaeus on Trinity (Supplements to Vigiliae Christianae 127). Leiden: Brill.

Kereszty RA (1984) The Unity of the Church in the Theology of Irenaeus. Second Century 4(4): 202-218.

MacDonald N (2009) Israel and the Old Testament Story in Irenaeus's Presentation of the Rule of Faith. Journal of Theological Interpretation 3(2): 281-298.

Meyer MW (ed) (2007) The Nag Hammadi Scriptures. New York: HarperCollins.

Rousseau A (1995) Démonstration de la prédication apostolique (Sources chrétiennes 406). Paris: Éditions du Cerf.

Rousseau A and Doutreleau L (eds) (1979) Irénée de Lyon: Contre les hérésies, Livre 1 (Sources chrétiennes 264). Paris: Éditions du Cerf.

Steenberg IMC (2008) Irenaeus on Creation: The Cosmic Christ and the Saga of Redemption (Supplements to Vigiliae Christianae 91). Leiden: Brill. 
Steenberg MC (2011) The Gospel of Truth and the Truth of the Gospel: Assessing the Scope of Valentinian Influence on the Thought of St. Irenaeus. Studia Patristica 50(*): 89-104.

Thomassen E (2006) The Pleromatology. In The Spiritual Seed: The Church of the 'Valentinians' (Nag Hammadi and Manichaean Studies 60). Leiden: Brill: 193-247. 